\title{
Additivity of apparent and standardized ileal digestibility of amino acid determined by chromic oxide and titanium dioxide in mixed diets containing wheat and multiple protein sources fed to growing pigs
}

\author{
Tingting Wang, Saheed Oladipupo Osho, and Olayiwola Adeola ${ }^{1}$
}

Department of Animal Sciences, Purdue University, West Lafayette, IN 47907

\begin{abstract}
The aim of this study was to investigate the additivity of apparent ileal digestibility (AID) and standardized ileal digestibility (SID) of crude protein $(\mathbf{C P})$ and amino acids (AA) in mixed diets containing wheat, canola meal $(\mathbf{C M})$, meat and bone meal (MBM), and sorghum distillers' dried grains with solubles (DDGS) fed to pigs with chromic oxide $\left(\mathrm{Cr}_{2} \mathbf{O}_{3}\right)$ and titanium dioxide $\left(\mathrm{TiO}_{2}\right)$ as digestibility index markers. Four diets were prepared to contain wheat, CM, MBM, or DDGS as a sole source of nitrogen; three mixed diets were prepared to contain wheat, $\mathrm{CM}$, and MBM; wheat, MBM, and DDGS; or wheat, CM, MBM, and DDGS; also, a nitrogen-free diet was prepared to estimate the basal ileal endogenous losses (BEL) of $\mathrm{CP}$ and AA. Both $\mathrm{Cr}_{2} \mathrm{O}_{3}$ and $\mathrm{TiO}_{2}$ were incorporated at $5 \mathrm{~g} / \mathrm{kg}$ into each diet. Sixteen barrows (initial body weight $=34.7 \pm 0.6 \mathrm{~kg}$ ) surgically fitted with T-cannulas at the distal ileum were allotted to a duplicate $8 \times 4$ Youden square design with eight experimental diets and four periods. During each 7-d period, the ileal digesta was collected for $2 \mathrm{~d}$ after a 5-d adaptation, and the AID and SID of CP and AA were determined using $\mathrm{Cr}_{2} \mathrm{O}_{3}$ or $\mathrm{TiO}_{2}$ as marker. There was no interaction between diet and marker type for both AID and SID of CP and AA. Similar BEL, AID, and SID of CP and AA were
\end{abstract}

determined by $\mathrm{Cr}_{2} \mathrm{O}_{3}$ and $\mathrm{TiO}_{2}$. In the wheat-CMMBM diet, the measured AID of CP and most AA determined with $\mathrm{Cr}_{2} \mathrm{O}_{3}$ or $\mathrm{TiO}_{2}$ were not different from the predicted values, which was determined based on the measured AID values in wheat, CM, and MBM. In the wheat-MBM-DDGS diet, the measured and predicted AID of $\mathrm{CP}$ and seven indispensable AA differed $(P<0.05)$ using $\mathrm{Cr}_{2} \mathrm{O}_{3}$ as marker, and the measured and predicted AID of $\mathrm{CP}$ and four indispensable AA differed $(P<0.05)$ using $\mathrm{TiO}_{2}$ as marker. The measured AID of $\mathrm{CP}$ and most indispensable AA were greater $(P<0.05)$ than predicted AID regardless of marker type for the wheat-CM-MBM-DDGS diet. The measured SID of CP and indispensable AA were consistent with the predicted values, except Lys in the wheatCM-MBM diet using either marker and His in the wheat-MBM-DDGS diet with $\mathrm{Cr}_{2} \mathrm{O}_{3}$ as marker. In conclusion, more accurate prediction of ileal digestibility of $\mathrm{CP}$ and $\mathrm{AA}$ was achieved using SID rather than AID in mixed diets containing wheat, CM, MBM, and DDGS. The determination of endogenous loss, AID, and SID of CP and AA were not affected by marker type in this study. In addition, the additivity of AID and SID of $\mathrm{CP}$ and most indispensable AA in mixed diets was not affected by marker type.

Key words: additivity, chromic oxide, ileal digestibility, swine, titanium dioxide

(C) The Author (s) 2018. Published by Oxford University Press on behalf of the American Society of Animal Science. All rights reserved. For permissions, please e-mail: journals.permissions@oup.com.

J. Anim. Sci. 2018.96:4731-4742 doi: $10.1093 /$ jas/sky326

\section{INTRODUCTION}

${ }^{1}$ Corresponding author: ladeola@purdue.edu

Received May 11, 2018.

Accepted August 8, 2018.
The application of additive ileal digestibility of amino acids (AA) in feed ingredients is fundamental to match AA supply in diets to AA requirement for pigs (Jansman et al., 2002). The 
standardized ileal digestible AA is adopted to express both requirements for pigs and ingredient contents used in feed formulation (NRC, 2012). Compared with apparent ileal digestibility (AID) of AA, the standardized ileal digestibility (SID) accounts for basal ileal endogenous losses (BEL) of AA; therefore, SID is independent of dietary AA contents and more additive in mixed diets fed to pigs, especially for the diets containing low-protein cereal grain (Stein et al., 2007). Lack of additivity of AID has been reported in the mixed diets containing corn in pigs (Stein et al., 2005; Xue et al., 2014); however, the additivity of AID in the mixed diet containing wheat is still not clear. According to NRC (2012), the crude protein (CP) content in soft red wheat is $2.7 \%$ greater than yellow dent corn, and this difference in CP content might elicit a relatively large change of AID in ingredients (Fan et al., 1994), as well as the additivity of AID in mixed diets.

One of the general approaches to determine ileal digestibility of $\mathrm{CP}$ and AA is to include digestibility index marker in diets and collect representative ileal digesta from pigs fitted with simple T-cannulas (Nyachoti et al., 1997a; Gabert et al., 2001). Chromic oxide $\left(\mathbf{C r}_{2} \mathbf{O}_{3}\right)$ and titanium dioxide $\left(\mathbf{T i O}_{2}\right)$ as two of the most common markers have been reported to affect the determination of ileal digestibility (Kavanagh et al., 2001; Wang et al., 2017), and this might relate to the variant recovery of these two markers in ileal digesta of pigs (Yin et al., 2000). Therefore, the choice of marker could affect the determination of ileal digestibility, consequently the additivity of ileal digestibility of $\mathrm{CP}$ and $\mathrm{AA}$ in mixed diets. In previous studies that investigated the assumption of additivity of AID and SID of CP and AA in mixed diets, $\mathrm{Cr}_{2} \mathrm{O}_{3}$ has been generally used as marker (Fan et al., 1993; Stein et al., 2005; Xue et al., 2014); however, there is a scarcity of data with $\mathrm{TiO}_{2}$ as marker. Thus, the objective of this experiment was to test the null hypothesis that 1) additivity of AID of CP and AA in mixed diets containing wheat, CM, MBM, and DDGS is not different from SID; 2) the determination of AID, SID, and BEL of CP and AA as well as additivity of ileal digestibility is not affected by the choice of marker.

\section{MATERIALS AND METHODS}

All animal procedures used in this study were approved by the Purdue University Animal Care and Use Committee.

\section{Dietary Treatments}

Eight experimental diets including one nitrogen-free diet (NFD) were formulated (Table 1). Four semipurified diets consisted one of wheat, canola meal (CM), meat and bone meal (MBM), or sorghum distillers' dried grains with solubles (DDGS) as the sole source of CP and AA to measure the AID and SID of CP and AA in test ingredients, which were used to determine the predicted AID and SID of CP and AA in mixed diets. Three mixed diets including wheat-CM-MBM, wheat-MBM-DDGS, and wheat-CM-MBMDDGS diets were formulated to contain approximately $17 \% \mathrm{CP}$ and measure the AID and SID of $\mathrm{CP}$ and $\mathrm{AA}$ in mixed diets. Wheat and MBM contents were same across the three mixed diets, but the CM and DDGS contents varied among the three mixed diets. All diets were formulated to meet or exceed the estimated vitamin and mineral requirements suggested in NRC (2012). Both $\mathrm{Cr}_{2} \mathrm{O}_{3}$ and $\mathrm{TiO}_{2}$ were incorporated into experimental diets as the marker at the level of $5 \mathrm{~g} / \mathrm{kg}$, respectively.

\section{Animals and Sample Collection}

Sixteen barrows (initial body weight = $34.7 \pm 0.6 \mathrm{~kg}$ ) were surgically fitted with T-cannulas at the distal ileum as described by Dilger et al. (2004). Pigs were allotted to two blocks with body weight as the blocking factor and assigned to a duplicate $8 \times 4$ Youden square design with eight dietary treatments and four experimental periods. All pigs were individually housed in stainless steel crates $(1.22 \times 1.22 \mathrm{~m})$ equipped with a feeder and a nipple drinker. Daily feed allowance was set as $4 \%$ of the initial smallest body weight in each block in each period, and pigs were fed at 0800 and $1700 \mathrm{~h}$ in two equally divided meals. Water was available at all time during the experiment. In each period, there were $5 \mathrm{~d}$ of adaptation and $2 \mathrm{~d}$ of ileal digesta collection. On day 6 and 7 of each experimental period, Whirl-Pak bag (Nasco, Fort Atkinson, WI) containing $10 \mathrm{~mL}$ of $10 \%$ formic acid was attached to the T-cannula with a rubber O-ring to collect ileal digesta from 0800 to $1700 \mathrm{~h}$. The attached bags were inspected every $30 \mathrm{~min}$ and the filled bags were changed and stored at $-20^{\circ} \mathrm{C}$ until further processing. The ileal digesta from each pig during each period were pooled, subsampled, and lyophilized. 
Table 1. Ingredient composition of experimental diets, $\%$ as-fed basis ${ }^{1}$

\begin{tabular}{|c|c|c|c|c|c|c|c|c|}
\hline Item & NFD & Wheat & $\mathrm{CM}$ & MBM & DDGS & Wheat-CM-MBM & Wheat-MBM-DDGS & Wheat-CM-MBM-DDGS \\
\hline Wheat & - & 88.90 & - & - & - & 58.00 & 58.00 & 58.00 \\
\hline Corn starch & 72.40 & - & 47.50 & 64.40 & 30.90 & 9.60 & 3.00 & 6.90 \\
\hline DDGS & - & - & - & - & 58.50 & - & 24.40 & 10.00 \\
\hline $\mathrm{CM}$ & - & - & 42.50 & - & - & 17.80 & - & 10.50 \\
\hline MBM & - & - & - & 27.00 & - & 6.00 & 6.00 & 6.00 \\
\hline Dextrose & 10.00 & - & - & - & - & - & - & - \\
\hline Cellulose $^{2}$ & 5.00 & - & - & - & - & - & - & - \\
\hline Soybean oil & 3.00 & 3.00 & 3.00 & 3.00 & 3.00 & 3.00 & 3.00 & 3.00 \\
\hline Monocalcium phosphate & 2.80 & 1.50 & 0.70 & - & 0.70 & - & - & - \\
\hline Chromic oxide premix ${ }^{3}$ & 2.50 & 2.50 & 2.50 & 2.50 & 2.50 & 2.50 & 2.50 & 2.50 \\
\hline Titanium dioxide premix ${ }^{4}$ & 2.50 & 2.50 & 2.50 & 2.50 & 2.50 & 2.50 & 2.50 & 2.50 \\
\hline Limestone & 0.60 & 1.00 & 0.70 & - & 1.30 & - & - & - \\
\hline Salt & 0.40 & 0.30 & 0.30 & 0.30 & 0.30 & 0.30 & 0.30 & 0.30 \\
\hline Potassium carbonate & 0.40 & - & - & - & - & - & - & - \\
\hline Vitamin premix ${ }^{5}$ & 0.15 & 0.15 & 0.15 & 0.15 & 0.15 & 0.15 & 0.15 & 0.15 \\
\hline Mineral premix ${ }^{6}$ & 0.10 & 0.10 & 0.10 & 0.10 & 0.10 & 0.10 & 0.10 & 0.10 \\
\hline Magnesium oxide & 0.10 & - & - & - & - & - & - & - \\
\hline Selenium premix ${ }^{7}$ & 0.05 & 0.05 & 0.05 & 0.05 & 0.05 & 0.05 & 0.05 & 0.05 \\
\hline Total & 100.00 & 100.00 & 100.00 & 100.00 & 100.00 & 100.00 & 100.00 & 100.00 \\
\hline
\end{tabular}

${ }^{1} \mathrm{NFD}=$ nitrogen-free diet; $\mathrm{CM}$ = canola meal; $\mathrm{MBM}=$ meat and bone meal; DDGS = sorghum distillers' dried grains with solubles.

${ }^{2}$ Solka-Floc 40 FCC, International Fiber Corporation, Urbana, OH.

${ }^{3} \mathrm{~A} 5 \mathrm{~g}$ chromic oxide was added to $20 \mathrm{~g}$ corn starch to provide $5 \mathrm{~g}$ chromic oxide $/ \mathrm{kg}$ of complete diet.

${ }^{4} \mathrm{~A} 5 \mathrm{~g}$ titanium dioxide was added to $20 \mathrm{~g}$ corn starch to provide $5 \mathrm{~g}$ titanium dioxide $/ \mathrm{kg}$ of complete diet.

${ }^{5}$ Provided the following quantities per kilogram of complete diet: vitamin A, 3,960 IU; vitamin $\mathrm{D}_{3}$, 396 IU; vitamin E, 26.4 IU; menadione, $1.30 \mathrm{mg}$; riboflavin, $5.30 \mathrm{mg}$; D-pantothenic acid, $13.2 \mathrm{mg}$; niacin, $19.8 \mathrm{mg}$; vitamin $\mathrm{B}_{12}, 0.02 \mathrm{mg}$.

${ }^{6}$ Provided the following quantities per kilogram of complete diet: $\mathrm{Cu}$ (as copper chloride), $9 \mathrm{mg}$; $\mathrm{Fe}$ (as ferrous carbonate), $194 \mathrm{mg}$; I (as calcium iodate), $0.36 \mathrm{mg}$; Mn (as manganese oxide), $17 \mathrm{mg}$; $\mathrm{Zn}$ (as zinc oxide), $149 \mathrm{mg}$.

${ }^{7}$ Provided $0.3 \mathrm{mg} \mathrm{Se} / \mathrm{kg}$ of complete diet.

\section{Chemical Analysis}

Ingredients, experimental diets, and ileal digesta samples were ground through a $0.5-\mathrm{mm}$ screen in a centrifugal grinder (Retsch ZM 200; Retsch GmbH, Haan, Germany). The concentrations of dry matter (DM) in ingredients, diets, and ileal digesta samples were measured by drying in a forced-air drying oven at $105^{\circ} \mathrm{C}$ for $24 \mathrm{~h}$ (Precision Scientific Co., Chicago, IL; method 934.01; AOAC, 2006). In ingredients, ether extract was analyzed without acid hydrolysis [method 920.39 (A); AOAC, 2006], and acid detergent fiber [method 973.18 (AD); AOAC, 2006] and neutral detergent fiber (Van Soest et al., 1991) contents were analyzed by a fiber analyzer (ANKOM A2000 Fiber Analyzer, ANKOM Technology, Macedon, NY). Nitrogen contents in ingredients, diets, and ileal digesta samples were determined by the combustion method (TruMac N; LECO Corp., St. Joseph, MI; method 990.03; AOAC, 2000), and the $\mathrm{CP}$ content was calculated by multiplying 6.25 by the content of nitrogen. Amino acid analyses [method 982.30 E (a, b, c); AOAC, 2006] for the diets, ingredients, and ileal digesta samples were performed by the University of Missouri Experiment Station Chemical Laboratories (Columbia, MO). The concentrations of $\mathrm{Cr}$ and $\mathrm{Ti}$ were analyzed as described by Saha and Gilbreath (1991) and Myers et al. (2004), respectively, with modifications as described by Wang and Adeola (2018).

\section{Calculations and Statistical Analysis}

The measured AID, BEL, and SID of CP and AA were determined using the following equations (Park et al., 2017):

$$
\begin{gathered}
\mathrm{AID}(\%)=\left(1-\left[\frac{M_{i}}{M_{o}}\right] \times\left[\frac{\mathrm{AA}_{o}}{\mathrm{AA}_{i}}\right]\right) \times 100 ; \\
\mathrm{BEL}(\mathrm{g} / \mathrm{kg} \mathrm{DM} \text { intake })=\mathrm{AA}_{o} \times\left(\frac{M_{i}}{M_{o}}\right) ; \\
\operatorname{SID}(\%)=\mathrm{AID}+\left(\frac{\mathrm{BEL}}{\mathrm{AA}_{i}}\right) \times 100,
\end{gathered}
$$


where $M_{i}$ and $M_{\mathrm{o}}$ are marker concentration $(\mathrm{g} / \mathrm{kg}$ $\mathrm{DM}$ ) of diet and ileal digesta, respectively; $\mathrm{AA}_{i}$ and $\mathrm{AA}_{o}$ are the $\mathrm{CP}$ or AA concentration $(\mathrm{g} / \mathrm{kg} \mathrm{DM})$ of diet and ileal digesta, respectively. The average $\mathrm{BEL}$ of $\mathrm{CP}$ and $\mathrm{AA}$ were calculated from the eight pigs received the NFD to determined SID from AID.

The predicted AID or SID of CP and AA in mixed diets were determined by the measured AID or SID of CP and AA in ingredients using the following equations (Xue et al., 2014):

$$
\operatorname{AID}_{p}(\%)=\frac{\begin{array}{c}
\left(\left[\mathrm{CP}_{\mathrm{w}} \times \mathrm{AID}_{\mathrm{w}}\right]+\left[\mathrm{CP}_{\mathrm{CM}} \times \mathrm{AID}_{\mathrm{CM}}\right]\right. \\
\left.+\left[\mathrm{CP}_{\mathrm{MBM}} \times \mathrm{AID}_{\mathrm{MBM}}\right]+\left[\mathrm{CP}_{\mathrm{DDGS}} \times \mathrm{AID}_{\mathrm{DDGS}}\right]\right)
\end{array}}{\left(\mathrm{CP}_{\mathrm{W}}+\mathrm{CP}_{\mathrm{CM}}+\mathrm{CP}_{\mathrm{MBM}}+\mathrm{CP}_{\mathrm{DDGS}}\right)},
$$

where $\mathrm{AID}_{p}$ is the predicted AID of CP in a mixed diet; $\mathrm{CP}_{\mathrm{W}}, \mathrm{CP}_{\mathrm{CM}}, \mathrm{CP}_{\mathrm{MBM}}$, and $\mathrm{CP}_{\mathrm{DDGS}}$ are the concentrations (\%) of $\mathrm{CP}$ in the mixed diets originating from wheat, CM, MBM, and DDGS, respectively, which were determined by multiplying the concentration of $\mathrm{CP}(\%)$ in respective ingredient by the proportion (\%) of the ingredient in mixed diet; $\mathrm{AID}_{\mathrm{W}}, \mathrm{AID}_{\mathrm{CM}}, \mathrm{AID}_{\mathrm{MBM}}$, and $\mathrm{AID}_{\mathrm{DDGS}}$ are the measured AID (\%) of CP in wheat, CM, MBM, and DDGS, respectively. The predicted AID of each AA in mixed diets was determined using the same equation by replacing $\mathrm{CP}$ with $\mathrm{AA}$ in the above equation. The predicted SID of $\mathrm{CP}$ or each $\mathrm{AA}$ in mixed diets was determined using the same equation with AID by replacing the AID with SID (\%) of CP or each AA in wheat, CM, MBM, and DDGS. The differences between measured and predicted values of AID or SID of CP and AA in the mixed diets were determined with both $\mathrm{Cr}_{2} \mathrm{O}_{3}$ and $\mathrm{TiO}_{2}$ as markers.

The data on AID and SID of CP and AA were analyzed using the MIXED procedure of statistical analysis system (SAS; SAS Inst. Inc., Cary, NC) as a split-plot arrangement, with dietary treatment as whole-plot factor and the marker type as splitplot factor. The model included diet, marker type, and the interaction between diet and marker type as fixed effects; and pig, period, and interactions between pig and period, pig and marker, and period and marker as random effects. The BEL data were analyzed using the MIXED procedure with marker type as fixed effect; and pig, period, and interaction between pig and marker as random effects. One-sample, two-tailed $t$-test was conducted by the TTEST procedure of SAS to test the null hypothesis that the difference between measured and predicted AID or SID of CP and AA in mixed diets is equal to 0 . The ileal digestibility was underestimated when the difference between measured and predicted values was significantly greater than 0 or was overestimated when the difference was significantly less than 0 . The experimental unit was pig in all the analyses, and statistical significance was declared at $P<0.05$.

\section{RESULTS}

All pigs were in good condition throughout the four periods of the experiment. Among the four feed ingredients used in this study, the concentration of CP ranged from $11.19 \%$ in wheat to $60.31 \%$ in MBM and similarly, the Lys concentration ranged from $0.36 \%$ in wheat to $2.73 \%$ in MBM (Table 2). Except for the NFD and wheat diet, the other experimental diets contained approximately $17 \%$ CP (Table 3 ).

There were no differences in the BEL of CP and all AA determined with $\mathrm{Cr}_{2} \mathrm{O}_{3}$ or $\mathrm{TiO}_{2}$ in pigs fed the NFD (Table 4). There was no interaction between experimental diet and marker type for both AID and SID of CP and AA, however, the values of AID and SID of CP and AA determined by both markers are presented in Tables 5 and 6 . The AID of CP, DM, and AA, and SID of CP and AA in each experimental diet were not affected by the choice of marker.

In the wheat-CM-MBM diet, the measured AID of His, Lys, Trp, and Tyr determined with either marker and AID of Thr, Asp, and Pro determined with $\mathrm{TiO}_{2}$ were greater $(P<0.05)$ than predicted values (Table 7). In the wheat-MBM-DDGS diet, the measured AID of CP, Arg, His, Lys, Trp, Pro, and Tyr determined with either marker and those of Ile, Leu, and Met determined with $\mathrm{Cr}_{2} \mathrm{O}_{3}$ were greater $(P<0.05)$ than predicted values. Regardless of marker type, the AID of CP and all indispensable AA except Arg and Val in the wheat-CM-MBMDDGS diet was underestimated, where the predicted AID was lower $(P<0.05)$ than the measured AID.

The measured SID of Lys determined with either marker and SID of Gly determined with $\mathrm{Cr}_{2} \mathrm{O}_{3}$ were different $(P<0.05)$ from predicted SID in the mixed diet containing wheat, $\mathrm{CM}$, and MBM (Table 8). For the wheat-MBM-DDGS diet, the measured SID of His determined with $\mathrm{Cr}_{2} \mathrm{O}_{3}$ and those of Pro and Tyr determined with either marker were greater $(P<0.05)$ than corresponding predicted SID. The measured and predicted SID of all AA except Cys and Tyr differed $(P<0.05)$ regardless of marker in the wheat-CM-MBM-DDGS diet.

\section{DISCUSSION}

The nutrients composition in wheat, CM, and MBM in this study were within the range of 
Table 2. Analyzed nutrient composition in ingredients, $\%$ as-fed basis ${ }^{1}$

\begin{tabular}{|c|c|c|c|c|}
\hline Item & Wheat & Canola meal & Meat and bone meal ${ }^{2}$ & DDGS \\
\hline Dry matter & 88.55 & 90.49 & 92.94 & 86.32 \\
\hline Crude protein ${ }^{3}$ & 11.19 & 40.24 & 60.31 & 29.82 \\
\hline Acid detergent fiber & 3.41 & 19.12 & 5.43 & 9.38 \\
\hline Neutral detergent fiber & 16.09 & 25.49 & 35.49 & 27.97 \\
\hline Ether extract & 0.65 & 5.83 & 8.54 & 10.80 \\
\hline \multicolumn{5}{|c|}{ Indispensable amino acids } \\
\hline Arg & 0.51 & 2.14 & 3.75 & 1.10 \\
\hline His & 0.25 & 1.00 & 0.96 & 0.54 \\
\hline Ile & 0.40 & 1.62 & 1.96 & 1.33 \\
\hline Leu & 0.70 & 2.62 & 3.58 & 3.15 \\
\hline Lys & 0.36 & 2.03 & 2.73 & 0.72 \\
\hline Met & 0.16 & 0.73 & 0.78 & 0.43 \\
\hline Phe & 0.47 & 1.55 & 2.10 & 1.46 \\
\hline Thr & 0.30 & 1.53 & 1.82 & 1.02 \\
\hline $\operatorname{Trp}$ & 0.14 & 0.47 & 0.32 & 0.19 \\
\hline Val & 0.49 & 2.05 & 2.79 & 1.57 \\
\hline \multicolumn{5}{|l|}{ Dispensable amino acid } \\
\hline Ala & 0.40 & 1.61 & 3.93 & 2.12 \\
\hline Asp & 0.55 & 2.60 & 4.06 & 1.88 \\
\hline Cys & 0.25 & 0.95 & 0.79 & 0.48 \\
\hline Glu & 2.77 & 6.23 & 6.50 & 3.77 \\
\hline Gly & 0.47 & 1.85 & 6.77 & 1.03 \\
\hline Pro & 0.94 & 2.39 & 4.61 & 1.83 \\
\hline Ser & 0.41 & 1.23 & 2.19 & 1.07 \\
\hline Tyr & 0.26 & 1.02 & 1.47 & 1.05 \\
\hline
\end{tabular}

${ }^{1}$ DDGS $=$ sorghum distillers' dried grains with solubles.

${ }^{2}$ Acid and neutral detergent fiber in meat and bone meal probably represent gelatin and other components dissolved in the acid and neutral detergent solutions rather than fiber.

${ }^{3}$ Crude protein $=$ nitrogen $\times 6.25$.

reported values for these ingredients (Olukosi and Adeola, 2009; Urriola et al., 2009; NRC, 2012; Xue et al., 2014). Except for the wheat diet, the CP contents in semipurified and mixed diets met the requirement for pigs (NRC, 2012).

The BEL of CP and AA determined with either $\mathrm{Cr}_{2} \mathrm{O}_{3}$ or $\mathrm{TiO}_{2}$ in NFD in this study were within the range of values reported in previous studies (Zhai and Adeola, 2011; NRC, 2012; Park et al., 2013; Xue et al., 2014). Value for BEL of AA could be determined by several methods; however, feeding NFD is most widely used due to its simplicity (Adeola, 2001). Although the NFD method is straightforward, several studies have investigated the factors related with diet formulation or physiological status of pig, which might affect the determination of BEL values in pigs (Park et al., 2013; Kong et al., 2014). This study indicated that the determination of BEL of CP and AA were not affected by the choice of marker used in NFD. It is worth noting that the AID of DM was not affected by marker type, which therefore excludes the possibility for other errors that may result in a lack of additivity.
Similar to the determination of AID of DM, the choice of marker had no effect on the determination of AID and SID of CP and AA in all semipurified and mixed diets in this study, even with high dietary fiber. In corn-soybean meal-based and barley-wheat-soybean meal-based complete diets, however, greater AID of CP was determined with $\mathrm{TiO}_{2}$ compared with $\mathrm{Cr}_{2} \mathrm{O}_{3}$ (Jagger et al., 1992; Wang and Adeola, 2018). It has been reported that starch-enriched diet emptied faster from the stomach compared with wheat bran- and sugar beet pulp-enriched diets (Guerin et al., 2001). Therefore, it is reasonable to speculate that the different effect of marker on digestibility between current and previous studies might be caused by discrepant basal components in diets, which was corn starch in this study.

One of the advantages of using SID instead of AID of CP and AA in diet formulation for pigs is that SID is relatively additive in mixtures of feed ingredients (Furuya and Kaji, 1991; Nyachoti et al., 1997b; Stein et al., 2005; Xue et al., 2014). This is because that SID has been corrected for the 
Table 3. Analyzed nutrient composition in experimental diets, $\%$ as-fed basis ${ }^{1}$

\begin{tabular}{|c|c|c|c|c|c|c|c|c|}
\hline Item & NFD & Wheat & $\mathrm{CM}$ & MBM & DDGS & Wheat-CM-MBM & Wheat-MBM-DDGS & Wheat-CM-MBM-DDGS \\
\hline Dry matter & 87.88 & 87.72 & 88.18 & 90.82 & 87.52 & 88.02 & 87.92 & 87.85 \\
\hline Crude protein ${ }^{2}$ & 0.68 & 9.79 & 16.95 & 17.72 & 16.86 & 16.85 & 17.20 & 17.44 \\
\hline \multicolumn{9}{|c|}{ Indispensable amino acids } \\
\hline $\operatorname{Arg}$ & 0.01 & 0.47 & 0.96 & 1.08 & 0.62 & 0.97 & 0.74 & 0.84 \\
\hline His & 0.00 & 0.21 & 0.44 & 0.25 & 0.31 & 0.40 & 0.33 & 0.36 \\
\hline Ile & 0.02 & 0.37 & 0.73 & 0.59 & 0.74 & 0.69 & 0.64 & 0.65 \\
\hline Leu & 0.04 & 0.65 & 1.20 & 1.09 & 1.78 & 1.18 & 1.33 & 1.21 \\
\hline Lys & 0.01 & 0.29 & 0.91 & 0.81 & 0.41 & 0.78 & 0.53 & 0.64 \\
\hline Met & 0.01 & 0.14 & 0.32 & 0.22 & 0.25 & 0.28 & 0.24 & 0.25 \\
\hline Phe & 0.02 & 0.45 & 0.70 & 0.64 & 0.82 & 0.72 & 0.72 & 0.71 \\
\hline Thr & 0.01 & 0.27 & 0.70 & 0.53 & 0.58 & 0.59 & 0.50 & 0.53 \\
\hline $\operatorname{Trp}$ & 0.02 & 0.11 & 0.20 & 0.10 & 0.12 & 0.19 & 0.15 & 0.17 \\
\hline Val & 0.01 & 0.44 & 0.90 & 0.85 & 0.89 & 0.86 & 0.78 & 0.80 \\
\hline \multicolumn{9}{|c|}{ Dispensable amino acids } \\
\hline Ala & 0.02 & 0.36 & 0.75 & 1.21 & 1.23 & 0.82 & 0.94 & 0.85 \\
\hline Asp & 0.02 & 0.50 & 1.18 & 1.20 & 1.13 & 1.11 & 1.01 & 1.02 \\
\hline Cys & 0.01 & 0.21 & 0.42 & 0.23 & 0.29 & 0.40 & 0.28 & 0.36 \\
\hline Glu & 0.04 & 2.56 & 2.89 & 1.98 & 2.43 & 3.32 & 2.94 & 3.11 \\
\hline Gly & 0.02 & 0.44 & 0.88 & 2.07 & 0.61 & 1.09 & 0.90 & 1.01 \\
\hline Pro & 0.02 & 0.92 & 1.06 & 1.41 & 1.09 & 1.29 & 1.22 & 1.24 \\
\hline Ser & 0.01 & 0.36 & 0.59 & 0.61 & 0.58 & 0.59 & 0.56 & 0.57 \\
\hline Tyr & 0.01 & 0.29 & 0.44 & 0.40 & 0.54 & 0.45 & 0.47 & 0.45 \\
\hline
\end{tabular}

${ }^{1} \mathrm{NFD}=$ nitrogen-free diet; $\mathrm{CM}=$ canola meal; $\mathrm{MBM}=$ meat and bone meal; DDGS = sorghum distillers' dried grains with solubles.

${ }^{2}$ Crude protein $=$ nitrogen $\times 6.25$.

Table 4. Basal ileal endogenous losses of crude protein and amino acids in pigs fed nitrogen-free diet, $\mathrm{mg} /$ kg dry matter intake ${ }^{1,2}$

\begin{tabular}{|c|c|c|c|c|}
\hline Item & $\mathrm{Cr}_{2} \mathrm{O}_{3}$ & $\mathrm{TiO}_{2}$ & SEM & $P$-value \\
\hline Crude protein, $\mathrm{g} / \mathrm{kg}$ dry matter intake ${ }^{3}$ & 16.31 & 16.91 & 1.708 & 0.170 \\
\hline \multicolumn{5}{|l|}{ Indispensable amino acids } \\
\hline Arg & 503 & 520 & 71.2 & 0.203 \\
\hline His & 181 & 188 & 13.7 & 0.159 \\
\hline Ile & 368 & 383 & 28.4 & 0.148 \\
\hline Leu & 587 & 611 & 40.8 & 0.132 \\
\hline Lys & 741 & 774 & 75.6 & 0.149 \\
\hline Met & 91 & 95 & 10.5 & 0.182 \\
\hline Phe & 361 & 375 & 24.0 & 0.139 \\
\hline Thr & 540 & 560 & 43.7 & 0.136 \\
\hline $\operatorname{Trp}$ & 114 & 119 & 9.3 & 0.108 \\
\hline Val & 531 & 551 & 39.3 & 0.134 \\
\hline \multicolumn{5}{|l|}{ Dispensable amino acids } \\
\hline Ala & 576 & 598 & 50.0 & 0.162 \\
\hline Asp & 856 & 889 & 61.3 & 0.142 \\
\hline Cys & 179 & 185 & 12.5 & 0.138 \\
\hline Glu & 1,017 & 1,057 & 85.4 & 0.147 \\
\hline Gly & 1,241 & 1,285 & 186.6 & 0.213 \\
\hline Pro & 3,549 & 3,672 & 871.1 & 0.274 \\
\hline Ser & 466 & 483 & 41.5 & 0.154 \\
\hline Tyr & 276 & 286 & 18.0 & 0.145 \\
\hline
\end{tabular}

${ }^{1} \mathrm{Cr}_{2} \mathrm{O}_{3}=$ chromic oxide; $\mathrm{TiO}_{2}=$ titanium dioxide .

${ }^{2}$ Each least squares mean represents eight observations.

${ }^{3}$ Crude protein $=$ nitrogen $\times 6.25$. 


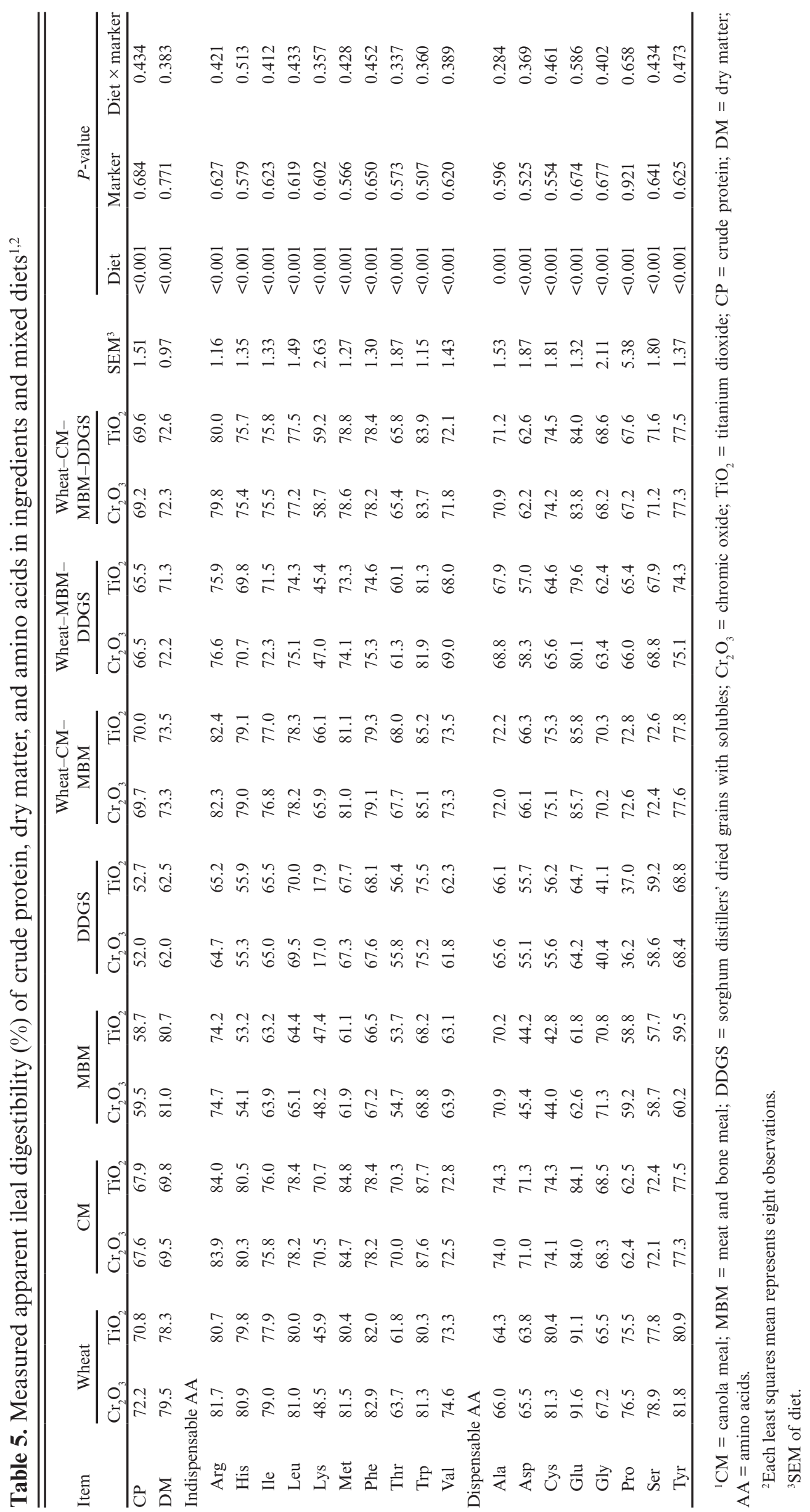


Wang et al.

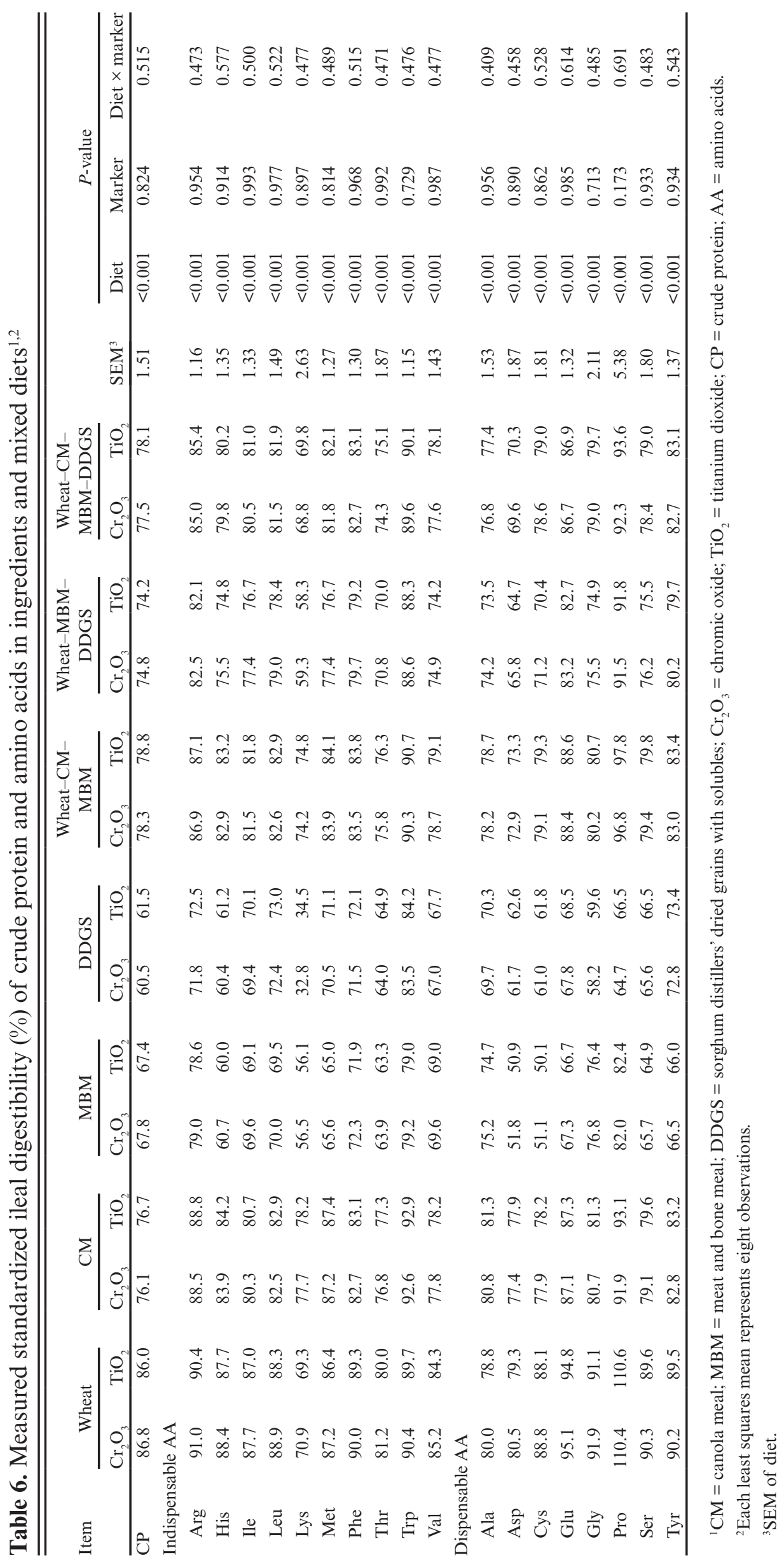


Table 7. Differences between measured and predicted values for apparent ileal digestibility (AID, \%) of crude protein and amino acids in mixed diets ${ }^{1,2}$

\begin{tabular}{|c|c|c|c|c|c|c|c|c|c|c|c|c|}
\hline \multirow[b]{3}{*}{ Item } & \multicolumn{4}{|c|}{ Wheat-CM-MBM } & \multicolumn{4}{|c|}{ Wheat-MBM-DDGS } & \multicolumn{4}{|c|}{ Wheat-CM-MBM-DDGS } \\
\hline & \multicolumn{2}{|c|}{$\mathrm{Cr}_{2} \mathrm{O}_{3}$} & \multicolumn{2}{|c|}{$\mathrm{TiO}_{2}$} & \multicolumn{2}{|c|}{$\mathrm{Cr}_{2} \mathrm{O}_{3}$} & \multicolumn{2}{|c|}{$\mathrm{TiO}_{2}$} & \multicolumn{2}{|c|}{$\mathrm{Cr}_{2} \mathrm{O}_{3}$} & \multicolumn{2}{|c|}{$\mathrm{TiO}_{2}$} \\
\hline & Diff & SE & Diff & SE & Diff & SE & Diff & SE & Diff & SE & Diff & SE \\
\hline$\overline{\mathrm{CP}}$ & 1.9 & 1.15 & 2.7 & 1.27 & $5.6^{* *}$ & 1.38 & $5.0^{* *}$ & 1.25 & $3.5^{*}$ & 1.36 & $4.4^{*}$ & 1.55 \\
\hline \multicolumn{13}{|c|}{ Indispensable AA } \\
\hline Arg & 1.3 & 0.73 & 1.8 & 0.82 & $2.7^{*}$ & 1.00 & $2.4^{*}$ & 0.87 & 0.6 & 1.13 & 1.2 & 1.26 \\
\hline His & $2.3^{*}$ & 0.86 & $2.9^{*}$ & 0.99 & $4.4^{* *}$ & 1.09 & $3.9^{*}$ & 1.14 & $2.5^{*}$ & 0.84 & $3.2^{*}$ & 1.14 \\
\hline Ile & 2.0 & 0.99 & 2.5 & 1.10 & $2.5^{*}$ & 0.86 & 1.9 & 0.90 & $2.9^{*}$ & 0.91 & $3.5^{*}$ & 1.09 \\
\hline Leu & 1.4 & 0.92 & 2.0 & 1.02 & $2.7^{*}$ & 1.04 & 2.1 & 0.93 & $2.6^{*}$ & 0.93 & $3.1^{*}$ & 1.14 \\
\hline Lys & $7.3^{* *}$ & 1.35 & $8.4^{* *}$ & 1.49 & $10.0^{*}$ & 2.88 & $9.3^{*}$ & 3.00 & $5.5^{*}$ & 1.97 & $6.8^{*}$ & 2.13 \\
\hline Met & 1.3 & 0.84 & 1.9 & 0.89 & $2.3^{*}$ & 0.85 & 1.8 & 0.86 & $2.0^{*}$ & 0.77 & $2.6^{*}$ & 0.91 \\
\hline Phe & 0.9 & 0.91 & 1.5 & 0.98 & 2.0 & 0.90 & 1.5 & 0.83 & $2.3^{*}$ & 0.79 & $2.8^{*}$ & 0.98 \\
\hline Thr & 2.7 & 1.29 & $3.6^{*}$ & 1.48 & 3.2 & 1.45 & 2.5 & 1.44 & $3.1^{*}$ & 0.98 & $4.0^{*}$ & 1.30 \\
\hline Trp & $2.2^{*}$ & 0.84 & $2.8^{*}$ & 0.86 & $4.2^{* *}$ & 0.88 & $4.1^{* *}$ & 1.02 & $2.6^{* *}$ & 0.67 & $3.3^{* *}$ & 0.82 \\
\hline Val & 1.7 & 1.05 & 2.4 & 1.18 & 2.3 & 1.12 & 1.7 & 1.02 & 2.2 & 0.99 & $3.0^{*}$ & 1.25 \\
\hline \multicolumn{13}{|c|}{ Dispensable AA } \\
\hline Ala & 1.4 & 1.11 & 2.3 & 1.24 & 1.8 & 1.26 & 1.1 & 1.08 & 1.9 & 1.15 & 2.7 & 1.35 \\
\hline Asp & 2.9 & 1.25 & $3.8^{*}$ & 1.50 & 2.3 & 1.79 & 1.5 & 1.99 & 1.5 & 1.15 & 2.5 & 1.54 \\
\hline Cys & 2.2 & 1.17 & 2.8 & 1.34 & -0.2 & 1.27 & -0.9 & 1.34 & $3.5^{* *}$ & 0.72 & $4.3^{* *}$ & 0.93 \\
\hline Glu & 0.5 & 0.55 & 0.8 & 0.65 & 1.0 & 0.85 & 0.5 & 0.79 & 0.9 & 0.65 & 1.3 & 0.80 \\
\hline Gly & -0.2 & 1.14 & 0.6 & 1.47 & 2.0 & 1.90 & 1.5 & 1.81 & -1.4 & 2.08 & -0.5 & 2.19 \\
\hline Pro & 4.9 & 2.25 & $5.5^{*}$ & 2.25 & $12.6^{* *}$ & 3.59 & $12.2^{* *}$ & 3.34 & -2.5 & 7.25 & -1.7 & 7.26 \\
\hline Ser & 0.4 & 1.10 & 1.2 & 1.22 & 2.5 & 1.46 & 1.9 & 1.41 & 1.3 & 1.03 & 2.1 & 1.28 \\
\hline Tyr & $2.3^{*}$ & 0.83 & $2.8^{*}$ & 0.95 & $4.0^{* *}$ & 0.91 & $3.5^{* *}$ & 0.87 & $3.9^{* *}$ & 0.72 & $4.4^{* *}$ & 0.92 \\
\hline
\end{tabular}

${ }^{1}$ Difference $=$ measured - predicted AID of CP and AA; predicted AID was determined based on the measured AID values in the feed ingredients contained in mixed diet.

${ }^{2} \mathrm{CM}=$ canola meal; $\mathrm{MBM}=$ meat and bone meal; DDGS = sorghum distillers' dried grains with solubles; $\mathrm{Cr}_{2} \mathrm{O}_{3}=$ chromic oxide; TiO ${ }_{2}=$ titanium dioxide; $\mathrm{CP}=$ crude protein; $\mathrm{AA}=$ amino acids; $\mathrm{Diff}=$ difference.

${ }^{*} P<0.05 ;{ }^{* *} P<0.01$. Ileal digestibility was underestimated when the difference between measured and predicted ileal digestibility was significantly greater than 0 or was overestimated when the difference was significantly less than 0 .

contribution of BEL of CP and AA in ileal digesta, and consequently SID is not affected by dietary CP content (Jansman et al., 2002). Similarly, this conclusion is also supported by the data from the three mixed diets in this study, where the differences between measured and predicted ileal digestibility values of $\mathrm{CP}$ and indispensable AA differed from zero in 39 for AID and 3 for SID of 66 observations.

The AID of His, Lys, Trp, and Tyr were not additive in all the three mixed diets, and the possible reason for this might be the low concentrations of these AA in the mixed diets, which could result in greater errors in the measurement of these AA. Cereal grains, such as corn and wheat, contribute a considerable proportion of AA to swine diets (Sauer et al., 2001), although their CP and AA concentrations are quite low. As discussed by Fan et al. (1994), the relationship between dietary AA content and AID value of respective AA is quadratic with plateau, and the plateau AID could be determined by meeting the threshold level of AA to become independent of the dietary AA content. When the direct method is used, the determination of AID of CP and AA in a cereal grain is generally underestimated because it is difficult to meet the threshold level of $\mathrm{CP}$ or AA in diet with a cereal grain as the sole source of $\mathrm{CP}$ or AA, and therefore underestimates the AID value in the mixed diet containing the cereal grain (Fan et al., 1994; Stein et al., 2005). This hypothesis was supported by Stein et al. (2005) and Xue et al. (2014), where the mixed diets containing corn resulted in lack of additivity. However, the AID of CP and most indispensable $\mathrm{AA}$ in the wheat-CM-MBM diet was additive regardless of the choice of marker in this study. The difference of additivity between corn and wheat might be explained by the greater $\mathrm{CP}$ and AA contents in wheat than corn, which can elicit a relatively large change in the determination of AID values (Fan et al., 1994). Furthermore, it has been reported that direct method did not underestimate the AID of AA in wheat compared with difference 
Table 8. Differences between measured and predicted values for standardized ileal digestibility (SID, \%) of crude protein and amino acids in mixed diets ${ }^{1,2}$

\begin{tabular}{|c|c|c|c|c|c|c|c|c|c|c|c|c|}
\hline \multirow[b]{3}{*}{ Item } & \multicolumn{4}{|c|}{ Wheat-CM-MBM } & \multicolumn{4}{|c|}{ Wheat-MBM-DDGS } & \multicolumn{4}{|c|}{ Wheat-CM-MBM-DDGS } \\
\hline & \multicolumn{2}{|c|}{$\mathrm{Cr}_{2} \mathrm{O}_{3}$} & \multicolumn{2}{|c|}{$\mathrm{TiO}_{2}$} & \multicolumn{2}{|c|}{$\mathrm{Cr}_{2} \mathrm{O}_{3}$} & \multicolumn{2}{|c|}{$\mathrm{TiO}_{2}$} & \multicolumn{2}{|c|}{$\mathrm{Cr}_{2} \mathrm{O}_{3}$} & \multicolumn{2}{|c|}{$\mathrm{TiO}_{2}$} \\
\hline & Diff & SE & Diff & $\mathrm{SE}$ & Diff & SE & Diff & SE & Diff & SE & Diff & SE \\
\hline$\overline{\mathrm{CP}}$ & -0.4 & 1.15 & 0.3 & 1.27 & 3.2 & 1.38 & 2.5 & 1.25 & 1.0 & 1.36 & 1.7 & 1.55 \\
\hline \multicolumn{13}{|c|}{ Indispensable AA } \\
\hline Arg & -0.2 & 0.73 & 0.2 & 0.82 & 1.6 & 1.00 & 1.2 & 0.87 & -0.7 & 1.13 & -0.1 & 1.26 \\
\hline His & 0.7 & 0.86 & 1.2 & 0.99 & $2.8^{*}$ & 1.09 & 2.2 & 1.14 & 1.0 & 0.84 & 1.6 & 1.14 \\
\hline Ile & 0.4 & 0.99 & 0.9 & 1.10 & 1.5 & 0.86 & 0.9 & 0.90 & 1.7 & 0.91 & 2.2 & 1.09 \\
\hline Leu & 0.0 & 0.92 & 0.5 & 1.02 & 1.9 & 1.04 & 1.3 & 0.93 & 1.6 & 0.93 & 2.1 & 1.14 \\
\hline Lys & $3.9^{*}$ & 1.35 & $4.8^{*}$ & 1.49 & 6.2 & 2.88 & 5.3 & 3.00 & 2.4 & 1.97 & 3.6 & 2.13 \\
\hline Met & 0.4 & 0.84 & 0.9 & 0.89 & 1.4 & 0.85 & 0.9 & 0.86 & 1.2 & 0.77 & 1.8 & 0.91 \\
\hline Phe & -0.3 & 0.91 & 0.2 & 0.98 & 1.2 & 0.90 & 0.7 & 0.83 & 1.3 & 0.79 & 1.8 & 0.98 \\
\hline Thr & 0.1 & 1.29 & 0.9 & 1.48 & 1.2 & 1.45 & 0.5 & 1.44 & 1.0 & 0.98 & 1.9 & 1.30 \\
\hline Trp & 0.1 & 0.84 & 0.6 & 0.86 & 1.9 & 0.88 & 1.7 & 1.02 & 0.6 & 0.67 & 1.1 & 0.82 \\
\hline Val & -0.1 & 1.05 & 0.6 & 1.18 & 1.1 & 1.12 & 0.5 & 1.02 & 0.9 & 0.99 & 1.6 & 1.25 \\
\hline \multicolumn{13}{|c|}{ Dispensable AA } \\
\hline Ala & -0.6 & 1.11 & 0.1 & 1.24 & 0.7 & 1.26 & 0.0 & 1.08 & 0.5 & 1.15 & 1.2 & 1.35 \\
\hline Asp & 0.6 & 1.25 & 1.4 & 1.50 & 0.5 & 1.79 & -0.3 & 1.99 & -0.3 & 1.15 & 0.7 & 1.54 \\
\hline Cys & 0.5 & 1.17 & 1.0 & 1.34 & -1.2 & 1.27 & -1.9 & 1.34 & $1.9^{*}$ & 0.72 & $2.5^{*}$ & 0.93 \\
\hline Glu & -0.3 & 0.55 & 0.0 & 0.65 & 0.3 & 0.85 & -0.1 & 0.79 & 0.2 & 0.65 & 0.6 & 0.80 \\
\hline Gly & $-3.1^{*}$ & 1.14 & -2.5 & 1.47 & -0.3 & 1.90 & -0.9 & 1.81 & -4.2 & 2.08 & -3.3 & 2.19 \\
\hline Pro & -0.9 & 2.25 & -0.4 & 2.25 & $8.6^{*}$ & 3.59 & $8.1^{*}$ & 3.34 & -7.2 & 7.25 & -6.5 & 7.26 \\
\hline Ser & -1.4 & 1.10 & -0.7 & 1.22 & 1.2 & 1.46 & 0.5 & 1.41 & -0.2 & 1.03 & 0.5 & 1.28 \\
\hline Tyr & 1.0 & 0.83 & 1.5 & 0.95 & $3.2^{* *}$ & 0.91 & $2.6^{*}$ & 0.87 & $2.9^{* *}$ & 0.72 & $3.4^{* *}$ & 0.92 \\
\hline
\end{tabular}

${ }^{1}$ Difference $=$ measured - predicted SID of CP and AA; predicted SID was determined based on the measured SID values in the feed ingredients contained in mixed diet.

${ }^{2} \mathrm{CM}=$ canola meal; $\mathrm{MBM}=$ meat and bone meal; DDGS = sorghum distillers' dried grains with solubles; $\mathrm{Cr}_{2} \mathrm{O}_{3}=$ chromic oxide; TiO ${ }_{2}=$ titanium dioxide; $\mathrm{CP}=$ crude protein; $\mathrm{AA}=$ amino acids; Diff = difference.

${ }^{*} P<0.05 ;{ }^{*} P<0.01$. Ileal digestibility was underestimated when the difference between measured and predicted ileal digestibility was significantly greater than 0 or was overestimated when the difference was significantly less than 0 .

and regression methods (Hennig et al., 2008), which supports the use of wheat as sole source of nitrogen to determine AID of AA.

The wheat-CM-MBM and wheat-MBMDDGS diets contained same levels of wheat and MBM to elucidate whether there was different effect between CM and DDGS on additivity of AID of $\mathrm{CP}$ and AA determined with the same marker. In the wheat-MBM-DDGS diet, AID of CP and four indispensable AA using $\mathrm{TiO}_{2}$ as marker, and of $\mathrm{CP}$ and seven indispensable $\mathrm{AA}$ using $\mathrm{Cr}_{2} \mathrm{O}_{3}$ as marker were underestimated. The lack of additivity observed with $\mathrm{TiO}_{2}$ and $\mathrm{Cr}_{2} \mathrm{O}_{3}$ in the wheatMBM-DDGS diet might relate to the low recovery of marker in the presence of high concentration of fiber from DDGS contained in this diet. It has been reported that the recovery of $\mathrm{TiO}_{2}$ was decreased from $99.9 \%$ to $67.8 \%$ and the recovery of $\mathrm{Cr}_{2} \mathrm{O}_{3}$ decreased from $84.9 \%$ to $60.6 \%$ with increasing dietary neutral detergent fiber concentration using pigs installed with post-valve T-caecum cannulas (Yin et al., 2000). Furthermore, a negative correlation between neutral detergent fiber and AID value of $\mathrm{CP}$ and AA determined with $\mathrm{Cr}_{2} \mathrm{O}_{3}$ has been reported (Fan et al., 2001); however, further research is required to investigate whether similarly negative correlation exists when $\mathrm{TiO}_{2}$ is chosen as marker.

Unlike in the mixed diets containing three feed ingredients, the AID of $\mathrm{CP}$ and indispensable AA were not additive in the wheat-CM-MBM-DDGS diet containing four feed ingredients using either $\mathrm{Cr}_{2} \mathrm{O}_{3}$ or $\mathrm{TiO}_{2}$ as marker. Except for dietary AA content, fiber source and level can also affect the threshold AA level in determination of AID of AA in ingredients, and therefore affect the predicted AID in mixed diets (Fan et al., 1994; Xue et al., 2014). However, the acid detergent fiber and neutral detergent fiber contents in the wheat-CMMBM-DDGS diet were between those in the other two mixed diets, which indicates fiber might not be the reason for the lack of additivity of AID of $\mathrm{CP}$ and AA in the wheat-CM-MBM-DDGS diet. On the other hand, four components were included in 
the determination of predicted AID values in the wheat-CM-MBM-DDGS diet, and this accumulative calculation could magnify the error in mixed diet induced by the calculation of determining AID for ingredients (Sauer et al., 2001); however, this speculation was not supported by the data in the study reported by Xue et al. (2014), and further study is required.

In conclusion, the SID of CP and AA are generally more accurate than AID for predicting ileal digestibility of $\mathrm{CP}$ and AA in mixed diets containing wheat, canola meal, meat and bone meal, and sorghum distillers' dried grains with solubles. The results of the experiment also demonstrate that the determination of endogenous loss, AID, and SID of $\mathrm{CP}$ and AA was not affected by the choice of digestibility index marker $\left(\mathrm{Cr}_{2} \mathrm{O}_{3}\right.$ or $\left.\mathrm{TiO}_{2}\right)$. In addition, the choice of digestibility index marker has no effect on the additivity of AID and SID of CP and most indispensable AA in all the three mixed diets.

\section{ACKNOWLEDGMENTS}

We gratefully acknowledge Dr. Darryl Ragland and Patricia Jaynes (Purdue University, West Lafayette, IN) for their considerable contribution to this study.

\section{LITERATURE CITED}

Adeola, O. 2001. Digestion and balance techniques in pigs. In: A. J. Lewis, and L. L. Southern, editors, Swine nutrition. 2nd ed. CRC Press, Washington, DC. p. 903-916.

AOAC. 2000. Official methods of analysis. 17th ed. Assoc. Off. Anal. Chem., Arlington, VA.

AOAC. 2006. Official methods of analysis. 18th ed. Assoc. Off. Anal. Chem., Arlington, VA.

Dilger, R. N., J. S. Sands, D. Ragland, and O. Adeola. 2004. Digestibility of nitrogen and amino acids in soybean meal with added soyhulls. J. Anim. Sci. 82:715-724. doi:10.252 7/2004.823715x.

Fan, M. Z., W. C. Sauer, R. T. Hardin, and K. A. Lien. 1994. Determination of apparent ileal amino acid digestibility in pigs: effect of dietary amino acid level. J. Anim. Sci. 72:2851-2859. doi:10.2527/1994.72112851x

Fan, M. Z., W. C. Sauer, and S. Li. 1993. The additivity of the digestible energy and apparent ileal digestible amino acid supply in barley, wheat and canola meal or soybean meal diets for growing pigs. J. Anim. Physiol. Anim. Nutr. 70:72-81. doi:10.1111/j.1439-0396.1993.tb00308.x

Fan, M. Z., W. C. Sauer, and S. Li. 2001. Variability of apparent ileal amino acid digestibility in high-protein wheat samples for growing-finishing pigs. J. Anim. Feed Sci. 10:103-118. doi:10.22358/jafs/67948/2001

Furuya, S., and Y. Kaji. 1991. Additivity of the apparent and true ileal digestible amino acid supply in barley, maize, wheat or soya-bean meal based diets for growing pigs. Anim. Feed Sci. Technol. 32:321-331. doi:10.1016/0377-8401(91)90036-R
Gabert, V. M., H. Jørgensen, and C. M. Nyachoti. 2001. Bioavailability of amino acids in feedstuffs for swine. In: A. J. Lewis, and L. L. Southern, editors, Swine nutrition. 2nd ed. CRC Press, Washington, DC. p. 146-181.

Guerin, S., Y. Ramonet, J. LeCloarec, M. C. Meunier-Salaün, P. Bourguet, and C. H. Malbert. 2001. Changes in intragastric meal distribution are better predictors of gastric emptying rate in conscious pigs than are meal viscosity or dietary fibre concentration. Br. J. Nutr. 85:343-350. doi:10.1079/BJN2000271

Hennig, U., W. Hackl, A. Priepke, A. Tuchscherer, W. B. Souffrant, and C. C. Metges. 2008. Comparison of ileal apparent, standardized and true digestibilities of amino acids in pigs fed wheat and lupine seeds. Livest. Sci. 118:61-71. doi:10.1016/j.livsci.2008.01.010

Jagger, S., J. Wiseman, D. J. Cole, and J. Craigon. 1992. Evaluation of inert markers for the determination of ileal and faecal apparent digestibility values in the pig. $\mathrm{Br}$. J. Nutr. 68:729-739. doi:10.1079/BJN19920129

Jansman, A. J. M., W. Smink, P. van Leeuwen, and M. Rademacher. 2002. Evaluation through literature data of the amount and amino acid composition of basal endogenous crude protein at the terminal ileum of pigs. Anim. Feed Sci. Technol. 98:49-60. doi:10.1016/ S0377-8401(02)00015-9

Kavanagh, S., P. B. Lynch, F. O'Mara, and P. J. Caffrey. 2001. A comparison of total collection and marker technique for the measurement of apparent digestibility of diets for growing pigs. Anim. Feed Sci. Technol. 89:49-58. doi:10.1016/S0377-8401(00)00237-6

Kong, C., D. Ragland, and O. Adeola. 2014. Ileal endogenous amino acid flow response to nitrogen-free diets with differing ratios of corn starch to dextrose in pigs. Asian-Australas. J. Anim. Sci. 27:1124-1130. doi:10.5713/ajas.2014.14232.

Myers, W. D., P. A. Ludden, V. Nayigihugu, and B. W. Hess. 2004. Technical note: a procedure for the preparation and quantitative analysis of samples for titanium dioxide. J. Anim. Sci. 82:179-183. doi:10.2527/2004.821179x

NRC. 2012. Nutrient requirements of swine. 11th rev. ed. Natl. Acad. Press, Washington, DC.

Nyachoti, C. M., C. F. M. de Lange, B. W. McBride, and H. Schulze. 1997a. Significance of endogenous gut nitrogen losses in the nutrition of growing pigs: A review. Can. J. Anim. Sci. 77:149-163. doi:10.4141/A96-044

Nyachoti, C. M., C. F. M. de Lange, and H. Schulze. 1997 b. Estimating endogenous amino acid flows at the terminal ileum and true ileal amino acid digestibilities in feedstuffs for growing pigs using the homoarginine method. J. Anim. Sci. 75:3206-3213. doi:10.2527/1997.75123206x

Olukosi, O. A., and O. Adeola. 2009. Estimation of the metabolizable energy content of meat and bone meal for swine. J. Anim. Sci. 87:2590-2599. doi:10.2527/jas.2009-1775.

Park, C. S., A. Helmbrecht, J. K. Htoo, and O. Adeola. 2017. Comparison of amino acid digestibility in full-fat soybean, two soybean meals, and peanut flour between broiler chickens and growing pigs. J. Anim. Sci. 95:3110-3119. doi:10.2527/jas.2017.1404.

Park, C. S., S. I. Oh, and B. G. Kim. 2013. Prediction of basal endogenous losses of amino acids based on body weight and feed intake in pigs fed nitrogen-free diets. Rev. Colomb. Cienc. Pecu. 26:186-192.

Saha, D. C., and R. L. Gilbreath. 1991. Analytical recovery of chromium from diet and faeces determined by colorimetry 
and atomic absorption spectrophotometry. J. Sci. Food Agric. 55:433-446. doi:10.1002/jsfa.2740550311

Sauer, W., J. He, M. Z. Fan, M. Cervantes, A. Kies, and W. Caine. 2001. Variability of amino acid digestibility in pigs: inherent factors in feedstuffs and considerations in methodology. J. Anim. Feed Sci. 10(Suppl. 1):115-138. doi:10.22358/jafs/70016/2001

Stein, H. H., C. Pedersen, A. R. Wirt, and R. A. Bohlke. 2005. Additivity of values for apparent and standardized ileal digestibility of amino acids in mixed diets fed to growing pigs. J. Anim. Sci. 83:2387-2395. doi:10.2527/2005.83102387x

Stein, H. H., B. Séve, M. F. Fuller, P. J. Moughan, and C. F. M. de Lange. 2007. Invited review: amino acid bioavailability and digestibility in pig feed ingredients: terminology and application. J. Anim. Sci. 85:172-180. doi:10.2527/jas.2005-742

Urriola, P. E., D. Hoehler, C. Pedersen, H. H. Stein, and G. C. Shurson. 2009. Amino acid digestibility of distillers dried grains with solubles, produced from sorghum, a sorghum-corn blend, and corn fed to growing pigs. J. Anim. Sci. 87:2574-2580. doi:10.2527/jas.2008-1436.

Van Soest, P. J., J. B. Robertson, and B. A. Lewis. 1991. Methods for dietary fiber, neutral detergent fiber, and nonstarch polysaccharides in relation to animal nutrition. J. Dairy Sci. 74:3583-3597. doi:10.3168/jds.S0022-0302(91)78551-2.
Wang, T., and O. Adeola. 2018. Digestibility index marker type, but not inclusion level affects apparent digestibility of energy and nitrogen and marker recovery in growing pigs regardless of added oat bran. J. Anim. Sci. 96:28172825. doi:10.1093/jas/sky153.

Wang, T., D. Ragland, and O. Adeola. 2017. Combination of digestibility marker and fiber affect energy and nitrogen digestibility in growing pigs. Anim. Feed Sci. Technol. 230:23-29. doi:10.1016/j.anifeedsci.2017.05.012

Xue, P. C., D. Ragland, and O. Adeola. 2014. Determination of additivity of apparent and standardized ileal digestibility of amino acids in diets containing multiple protein sources fed to growing pigs. J. Anim. Sci. 92:3937-3944. doi:10.2527/jas.2014-7815.

Yin, Y. L., J. D. G. McEvoy, H. Schulze, U. Hennig, W.-B. Souffrant, and K. J. McCracken. 2000. Apparent digestibility (ileal and overall) of nutrients as evaluated with PVTC-cannulated or ileo-rectal anastomised pigs fed diets containing two indigestible markers. Livest. Prod. Sci. 62:133-141. doi:10.1016/ S0301-6226(99)00130-X

Zhai, H., and O. Adeola. 2011. Apparent and standardized ileal digestibilities of amino acids for pigs fed corn- and soybean meal-based diets at varying crude protein levels. J. Anim. Sci. 89:3626-3633. doi:10.2527/jas.2010-3732. 